\title{
Nuclear Factor of Activated T-Cells, Cytoplasmic 4
}

National Cancer Institute

\section{Source}

National Cancer Institute. Nuclear Factor of Activated T-Cells, Cytoplasmic 4. NCI

Thesaurus. Code C93160.

Nuclear factor of activated T-cells, cytoplasmic 4 (902 aa, $~ 95 \mathrm{kDa}$ ) is encoded by the human NFAT C4 gene. This protein is involved in the modulation of cytokine gene expression, cell differentiation and the inflammatory response. 